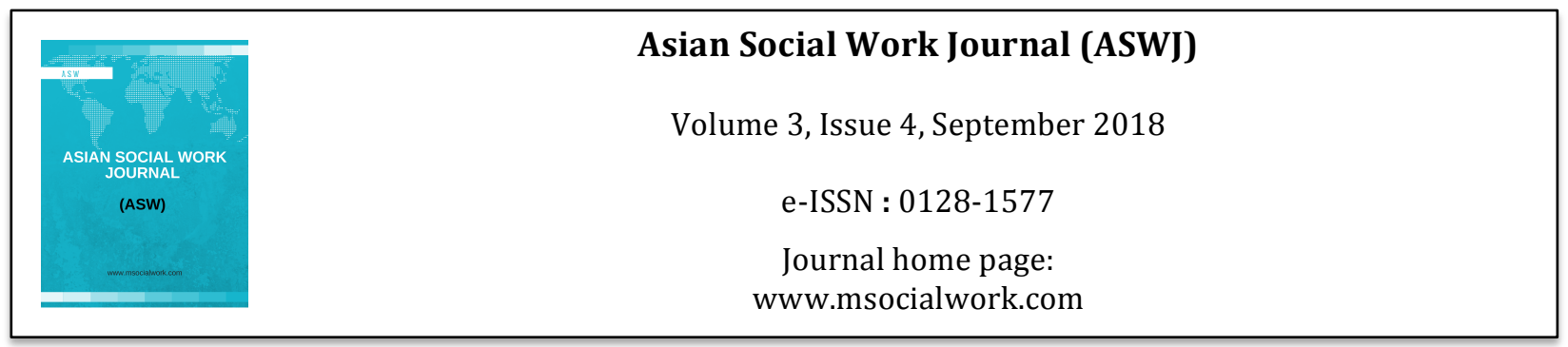

\title{
The Relationship of Parenting Styles of Parents and Exploration and Commitment in the Identity Formation of Occupations for Late Adolescents: A Study on the Identity Formation of Late Adolescents in the City and the Village
}

\author{
Ami Maryami ${ }^{1}$ \\ 1Bandung College of Social Welfare \\ Corrrespondence: Ami Maryami (maryami_ridzwan@yahoo.co.id)
}

\begin{abstract}
Ami Maryami, The Relationship of Parenting Styles of Parents and Exploration and Commitment on the Identity Formation of Occupations for Late Adolescents (A Study on the Identity Formation of Late Adolescents in the City and the Village). The research aims to find out 1) the relation of parenting styles of parents to exploration and commitment to the identity formation of occupations of late adolescents, 2) the different styles of parenting by parents, and 3) exploration and commitment differences on the identity formation of occupations of late adolescents, among those who live in the village and the city. The object of research is high school students who were in the third year (late adolescents) who live in Bandung Regency and the City of Bandung. The sampling technique used was two-cluster sampling, and $n=116$ was obtained for late adolescents in the village and 116 for the late adolescents in the city. To examine the hypothesis in order to see whether it has a correlation or not, Pearson Correlation was used, while the t-test was used to see whether there were any differences. The research result revealed that there is a correlation between parenting styles of parents and exploration and commitment on identity formation of occupations of late adolescents who live in the village and the city. There is no difference in parenting styles of parents who live in the village and the city, and there is no difference in identity formation of occupations of late adolescents in the village and the city, but there is a difference in commitment in identity formation of occupations of late adolescents among those in the village and the city.
\end{abstract}

Key words: parenting styles, exploration and commitment, identity formation, occupations

\section{Introduction}

The family is the first and foremost environment for the education of children, where children are guided so that they may be expected to play an active role in various fields in life. The guidance process that parents perform for their children is conducted through the caretaking process reflected in the interactions of parents and children. Good interactions among parents and children may help the development of the children, as families have an important function in creating a conducive situation for children so that children feel the warmth and affection of their parents.

The lives of adolescents that reside in villages are relatively short, unlike those that live in big cities. Adolescents in villages are prepared by parents to accept the adult responsibility of becoming a member of society. Adolescents in villages, from a young age, begin to be drawn into tasks related to the occupations that they will later on undertake. Adolescents in villages have been trained from a young age to partake in life in the communities where they reside. This condition becomes the outset 
for adolescents in villages to take up their occupational roles, for example by becoming involved with adults in everyday activities. The transition of adolescents in villages to execute the roles and responsibilities of adulthood begins at an early age; parents expect their children to work together in the occupation that belongs to their families. The preparation that adolescents undertake in becoming an adult is mostly gained from the experience of performing the same duties as those of adults (Laurence Steinberg: 1993).

In urban communities, the interactions that occur in the family environment has become very much different, where children have the audacity to express their thoughts, leading to the development of personal independence (M. Holil Mansyur, 1991). Adolescents in the city have a broad opportunity to develop themselves according to the potentials they possess, so that they may freely decide in what direction they will take their lives. This condition is inescapable from the support of other people, in particular, the openness of parents toward their children. Parents in cities have the tendency to direct adolescents to be able to explore their lives, so that they may determine what to be prepared for the future.

Grotevant and Cooper (in Archer, 1994) have the view that the treatment of children by their parents is realized through interactions that play an important role in the formation of adolescent identities through parenting styles. Hauser et al. (in Archer, 1994) classify parenting style as one of two styles: enabling or constraining. The parenting style of "enabling" is a parenting style that provides an opportunity for children to develop themselves by exploring their lives in an effort to achieve personal autonomy. The parenting style of "constraining" is a parenting style that does not provide an opportunity for children to develop themselves.

In relation to the formation of identities of occupations, family has a very important role, as expressed by Marcia (1993), in that the parenting style of parents is also expected to affect the characteristics of identities; this is possible because there are differences in the way parents convey expectations for their children or because of the process of identification. With the differences between the two parenting styles, the exploration and commitment process of a person can be seen. The "enabling" parenting style will provide contributions toward exploration and commitment, while the "constraining" parenting style will hinder the exploration and commitment process.

This research was conducted at Bandung Regency and the City of Bandung. The City of Bandung represents a city (urban) environment, while Bandung Regency represents a village (rural) environment. These are the problems of the research: 1) Is there a relationship between parenting styles and exploration and commitment in the formation of the identity of occupations for late adolescents living in the city and the village? 2) Is there a difference in parenting styles in the formation of the identity of occupations between late adolescents living in the city and the village? 3) Is there a difference in the formation of identity between late adolescents living in the city and the village?

\section{Literature Review}

In adolescence, there is a meaningful development of intellect, emotion, social relationships, morals, and personality. The intellectual (cognitive) development that occurs among adolescents has reached the stage of formal operations (Piaget, 1993) where adolescents can think logically about a variety of abstract ideas. Adolescents are able to solve problems correctly and to show broad insights or perspectives on these problems that they face (Sigelman and Shaffer, 1995).

According to Marcia (in Syamsu Yusuf, 2000), self-identity refers to the organization or regulation of ability motivations and beliefs into the image of oneself in a consistent manner, which covers the ability to select and make decisions. If adolescents fail to integrate aspects and choices or feel unable to choose, they will then experience confusion.

The aspect of exploration contains the components of the amount of knowledge, activities, consideration of alternatives from potential identity elements, and the desire to decide earlier. The 
aspect of commitment contains the components of the amount of knowledge, activities that are directed to apply the selected element of identity, emotional state, significant identification of other people, projections of the future, and resistance toward turbulence.

The "enabling" parenting style is a form of interaction between parents and children, where the parent creates an internal family situation by providing a sense of safety and a sense of possessing selfactualization, developing warm relationships with the children, acting respectfully, and encouraging children to express their feelings and opinions.

\section{Method}

The method used to test the hypothesis in this research is the descriptive method with correlation and difference testing. Correlation testing was conducted to test the relationship between parenting style (X) and exploration (Y1) and commitment (Y2) in the formation of the identity of occupations of late adolescents living in the village and the city. Meanwhile, difference testing was used to check for differences between parenting styles of parents living in the village (X1) and in the city (X2), differences of exploration of late adolescents living in the village (Y1.1) and in the city (Y1.2), and differences of commitment of late adolescents living in the village (Y2.1) and in the city (Y2.2).

The population in this research is adolescents limited by the criteria of those receiving formal education at Private or State High Schools (SMU), who were in their third grade between the ages of 18-22 years (late adolescents), residing in Bandung Regency which represents a village environment as well as the City of Bandung which represents a city environment. Based on calculations of the first and second iterations, the same value was obtained, and therefore the number of samples to be taken was $\mathrm{n}$ $=116$ respondents from third grade students of high schools in the City of Bandung, representing the city environment, and 116 respondents from third grade students of high schools in Bandung Regency, representing the village environment.

\section{Results}

Research results show that parenting styles have a significant relationship with exploration in the formation of the identity of occupations for late adolescents living in the village and the city. The parenting style of parents in the village and the city tends to be "enabling", meaning that parents provide the opportunity for late adolescents to express their thoughts and perceptions in determining the occupations that they will later undertake.

Research results also show that there is no relationship between parenting styles and the commitment of late adolescents. This has the indication that parents are still dominant in determining the occupations of adolescents in the village, making the adolescents less audacious (having less commitment); as such late adolescents in the village have a greater dependency to parents in determining occupations compared to late adolescents in the city.

In the research results, it is also shown that there is a difference in the commitment of late adolescents in the formation of the identity of occupations between those in the village and the city. This is because parents of those living in the city tend to be more democratic and reduce interference into adolescents in determining their occupations.

It is shown by the research results that there is no difference between the parenting styles of those in the village and the city. One of the factors that cause this is the level of education of the parents in the village, which is relatively moderate, and in the city, which tends to be high, so that the resulting patterns of thinking and attitudes influence how the parents conduct interactions with their late adolescents. 
It is also shown by the research results that there is no difference in exploration in the formation of the identity of occupations between late adolescents living in the village and the city. Activities that are done by late adolescents in both the village and the city provide equal opportunity to uncover the information they need to know in relation to the occupation that they would select.

Research results also show a difference in commitment in the formation of the identity of occupations between late adolescents living in the village and the city. This difference is affected by the concern of late adolescents in the village in determining occupations (based on an interview with an individual). Another factor that causes this difference in commitment was because adolescents in the village usually do not dare to go against what their parents have decided.

\section{Conclusions And Suggestions}

Based on the results of hypothesis testing, it can be concluded that there is a significant relationship between parenting styles of parents and exploration and commitment in the formation of the identity of occupations for late adolescents in the village and the city. Results of testing showed that the parenting styles of parents in both the village and the city tend to be "enabling", where parents provide the opportunity for late adolescents to conduct the activity of exploration and establish a commitment to the occupation they will select.

A suggestion that can be given to parents is that they are expected to provide the greatest opportunity for their children to know, understand, and uncover what can be known, because it is with this opportunity that children will obtain greater insights of this knowledge, so that later on children can conduct exploration of what their interests are. Parents should facilitate information regarding occupations, for example how late adolescents can make use of existing opportunities, as well as tips to obtain an occupation, so that late adolescents become more open to understand and get to know indepth about the working world.

\section{References}

Adam's, Gerald \& Gullota, Thomas. (1983). Adolescent Life Experience. California, Brooks Cole Publishing Company

Adelson, Joseph (ed). (1979). Handbook of Adolescent Psychology. New York, John Wiley \& Sons.

Archer, Sally L. (ed). (1994). Intervention for Adolescent Identity Development. London, Sage Publications.

Bintarto R. (1983). Interaksi Desa-Kota. Jakarta, Ghalia Indonesia.

Daljoeni. (1987). Seluk Beluk Masyarakat Kota. Bandung, Alumni

Erikson, Erik H. (1989). Identitas dan Siklus Hidup Manusia : Bunga Rampai I (Terjemahan), Jakarta, Gramedia.

Fuhrmann, Barbara S. (1990). Adolescence, Adolescent (Second Editions). London, Foresman and Company.

Friedenberg, Lisa (1995). Psychological Testing: Design, Analysis, and Use. America, Allyn, and Bacon.

Harun Al Rasyid. (!994). Dasar-dasar Statistik Terapan. Bandung, Program Pascasarjana Universitas Padjadjaran .

--oras (1995). Statistik Sosial. Bandung, Program Pascasarjana Universitas Padjadjaran .

Hurlock. E. (1992). Psikologi Perkembangan Suatu Pendekatan Sepanjang Rentang Kehidupan (Terjemahan), Jakarta, Erlangga.

Jefta Leibo. (1995). Sosiologi Pedesaan. Yogyakarta, Andi Ofset

Kerlinger, Fred N. (1995). Asas-asas Penelitian Behavioral (Terjemahan). Yogyakarta, Gajah Mada University Press

Lerner, M. Richard \& David E. Hultsch. (1983). Human Development: A Life-Span Perspective. New York, Mc Graw-Hill.Inc.

Marcia. J.E. (1988). Identity Diffusion Differentiated. Burnaby, Simon Fraser University 
(1989). The implication of Methodologies For Identity Theory: The Identity Status Interview. Burnaby, Simon Fraser University

(1989). The Identity Status Approach to The Study of Ego Identity Development. Burnaby, Simon Fraser University

Mansyur. M. Cholil (1991). Sosiologi Masyarakat Kota dan Desa. Surabaya, Usaha Nasional.

Melly Sulastri S. (1987). Psikologi Perkembangan Remaja. Jakarta, Bina Aksara

Monks,F.S. dkk. (1992). Psikologi Perkembangan, Yogyakarta, Gajahmada University Press.

Moh Nasir. (1986). Metode Penelitian. Jakarta, Ghalia Indonesia.

Papalia. Diane E. \& Old. Sally W. ( 1992). Human Development. ( Fifth Edition). New York, Mc. Graw-Hill, Inc.

Saifudin Azwar. (1997). Reliabilitas dan Validitas. Yogyakarta, Pusaka Pelajar (2000). Skala Psikologi. Yogyakarta, Pusaka Pelajar

Santrock, John W. (1997). Life - Span Development (Sixth Edition). Dallas, Brown \& Benchmark

Sapari Iman Asy'ari (1993). Sosiologi Kota dan Desa. Surabaya, Usaha Nasional

Soelaiman M.J. ((1994). Pendidikan Dalam Keluarga. Bandung, Alfabeta

Steinberg. Laurence. (1993). Adolescence. New York, Mc Graw-Hill, Inc.

Sugiono. (2000). Statistik Untuk Penelitian. Bandung, Alfabeta.

Sulastri S. Melly. (1987). Psikologi Perkembangan Remaja. Jakarta. Bina Aksara

Syamsu Yusuf. (2000). Psikologi Perkembangan Anak dan Remaja. Bandung, Remaja Rosda Karya. 